\title{
Supramaximal Temperature and Life Duration of the Ancient Fruit of Indian Lotus
}

\author{
By \\ I. Ohga \\ With 5 Text-Figures
}

INTRODUCTION

With regard to delayed germination of seeds, it is a weil known fact that the impermeable seed coat plays an important rôle. A study concerning hard-coated seeds has been made by BERGTHEIL and DAY ${ }^{(4)}$, WhITE ${ }^{(7)}$, CROCKER $^{(12)}$ and some others. CROCKFR ${ }^{(7)}$ (8)(9.(1))(11) scems to have opposed to the theory that the long life of a seed is, as a rule, to be attributed to the embryo character or to the dormancy of protoplasm, while EWART ${ }^{(14)}$ observes that it depends on the peculiar inherent property of the protoplasm. A seed, buried in the earth, is more or less safely guarded against various risks to which one in the air is exposed. And the degree of the protection varies according to the depth below the surface, so that the deeper down in the soil is the seed buried, thee longer is its life, as shown

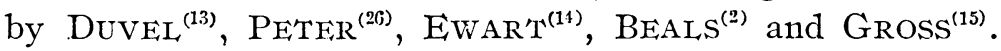

The present writer ${ }^{(21)(22)(23)}$ reported 1) that the hard coat of a century old fruit of the Indian Lotus found in the peat bed near Pulantien, South Manchuria, is very thick and its outside is covered with a layer of thick palisade cell, 2) that it stands the attack of concentrated sulphuric acid even for 24 hours, and also 3) that it is very rare that one sees a natural sprout in the laboratory or in the field where the fruit is located; he laid stress on the presence of this hard coat as the cause of long life of the fruit. After further study of the fruit kernel, he came to the conclusion that the long life of the Indian Lotus is due to its hard coat as well as the nature of embryo or protein substance contained in the fruit; namely as GuPpy $^{(17)}$ suggested, the longevity of the seed should be regarded as determined by two factors, represented in the impermeability of the coat and in the persistence of the protoplasmic constitution of the embryo kernel. So a combination of the theories of CROCKER and 
EWART seems to present the best working hypothesis. At any rate, the hard coat is impervious to the water and the plasm in the kernel is protected from respiration or any chemical actions. But in a long course of the time the protein substance will change its nature very slowly.

Respiration rate depends upon the water content of the plasm. In the wheat, $\mathrm{BABCOCK}^{-(1)}$ determined that when water content is about $10 \%$ there is no trace of respiration. In the Indian Lotus fruit, the water content is about $12.0 \%$ and when the writer ${ }^{(24)}$ analyzed its gas content in the ancient and new fruits by means of BONNIER and MANGIN's apparatus, he failed to find out any perceivable differences between the two. This fact proves that respiration which exhausts food substances is very very slow, and also when he ${ }^{(25)}$ measured the catalase activity of the ancient and new fruits by APPLEMAN's method, an amount of oxygen liberation from an old fruit was more than that from a new one. Though there may exist certain individual differences, it proves that the catalase activity did not perceivably decrease with the lapse of the time. These facts show that the theory that the loss of viability is due to the exhaustion of stored food by respiration or the decrease of the enzyme action is incorrect. As to the longevity of the Indian Lotus it requires further explanation.

Certain facts led us to surmise that the gradual loss of vitaiity is due to a slow coagulation of protein in the protoplasm of the embryo. The falling off in longevity with the rise of temperature and of moisture content of a seed seems to support this theory. Some very significant works have been done on such time and temperature relation of the coagulation of protein in vitro and in the living cell. BUGIIA ${ }^{(5)}$ found that the time required for the coagulation of blood serum varies with the temperature used. The time of coagulation has been found to be a logarithmic function of the temperature. CHICK and MARTIN ${ }^{(6)}$ found that the time required to obtain precipitated egg albumen and haemoglobin from a solution varies with temperature and with the concentration of the solution. LEPESCHKIN ${ }^{(19)}$ showed that the death of an active piant cell of Tradescantia and Beta by supramaximal temperature was due to the coagulation of the cell protoplasm. He applied a logarithmic formula to express the relation of temperature to the time of coagulation of proteins in the living cell. By the application of the formula to the determined time for coagulation, one can calculate the time required for coagulation at any other temperature. CROCKER 
and GROVFs ${ }^{(1)}$ applied LEPESCHKIn's formula for wheat seed treated by supramaximal temperature and found that the calculated number from the formula quite agreed with the longevity of the seed stored in the room temperature and that a seed kept at a higher temperature for a short time and one kept at a low temperature for a longer time show similar changes, namely, 1) delay in germination and 2) fall in germination rate. Assuming these facts as correct, the writer started some experiments about temperature-iife duration of the fruit of the ancient Indian Lotus. However, during his stay abroad, the material at his disposal was not sufficient to enable him to complete this experiment. Now in his home land, he has been able to collect quite a number of the fruits and to make experiments on. The results of these experiments are reported here. It may be mentioned that he is intending to summarize some of the data which he has done during these years.

\section{EXPERIMENTAL ME'THOHS}

In order to abtain constant temperature for heating the fruits, a water bath and an air bath were used and the experiment was conducted at temperatures between $70^{\circ}$ and $120^{\circ} \mathrm{C}$; in the case of temperature higher than $100^{\circ} \mathrm{C}$ an air bath was used and when less than $100^{\circ} \mathrm{C}$ a water bath. The water bath was cylindrical in shape, $30 \mathrm{~cm}$. in height and $35 \mathrm{~cm}$. in diameter. It was filled 'with hot water and covered with a thin layer of about $50^{\circ} \mathrm{C}$ paraffin. The bath was heated by gas and the temperature was reguiated by a xylol-mercury regulator. During the time of the experiment it showed fluctuations of less than $\pm 0.2^{\circ} \mathrm{C}$. This apparatus was devised by Dr. Y. HATTORI, a physico-chemist.

In order to heat the fruit in the bath it was placed in a $100 \mathrm{cc}$. flask filled with hot water of the same degree, or wrapped in a wire-netting dipped in the bath. After a certain time interval, 20 to 25 fruits were taken out. For higher temperature, the fruits were soaked in paraffin heated a little more than the degree required in the air bath. In two or three minutes the required temperature is obtained. The size of the fruit is quite big. It needs some minutes to conduct heat to the embryo. With a thermo-couple, the writer measured the time required to conduct the temperature from outside to the centre of the fruit in the air bath of $100^{\circ} \mathrm{C}$; this took about 10 minutes. So when in the water, it ought to be quicker than this, and owing to the difficulty of measuring the time in the water, it was assumed that the conduction of temperature from outside to the 
centre and vice versa was about equal. From this assumption, it would seem that some experimental error comes out at the high temperature.

Every fruit mass taken out of the bath at a certain interval was soaked in concentrated sulphuric acid in the test tube. After 15 to 20 hours, they were washed with running water and removed into tap water. Half an hour later, all the fruits swelled up and then they were coated off. These fruit masses were kept in an incubator at $35^{\circ} \mathrm{C}$. Though the sprout comes out in 3 days ordinarily, they were examined 5,7 or 10 days later as germination is delayed by heating.

According to my previous experimence, when the colour of the naked fruit is reddish brown, it shows that germination will occur. When, however, the colour of a naked one is greyish brown, no germination results. And so if any greyish brown seeds be found, they were all eliminated and only reddisin brown ones were removed into the incubator. In ten days, when the length of the sprout is 2 or $3 \mathrm{~mm}$., it was taken as germinated.

\section{EXPERIMFNTAL DaTA AND ITS MATHEMA'TICAL TRFATMENT}

The relation betwcen time of heating and rate of germination is shown in Fig. 1, Fig. 2, Fig. 3 and Fig. 4.

There is a gradual decrease in the rate of germination with increased time of heating and a fruit kept at a higher temperature for a short time and one kept at a lower temperature for a longer time develop the similar features.

The time required to kill all the fruit was taken as the terminal point, terminus ad quem. Table I shows all the data obtained.

Now, comparing the differences of the logarithins of the average times of the terminal point of germination, we find that those differences crrange themselves in two series of an arithmetical progression; one above $100^{\circ} \mathrm{C}$ and the other below $100^{\circ} \mathrm{C}$. At above $100^{\circ} \mathrm{C}$, the time of heating is very short and heat conductivity is very rapid. So some errors might be expected to come into the data. But below $100^{\circ} \mathrm{C}$, we can observe another common difference approximately 0.40. A series of these logarithms makes a straight line when plotting in co-ordinate. LFPESCHKIN from his experiment about Tradescantia and Beta suggested a logarithmic formula for timetemperature relation $\mathrm{T}=a-b \log \mathrm{Z}$, in which $\mathrm{T}$ is the temperature in degree Centigrade, $Z$ is the time in minutes and $a$ and $b$ are constants. As the logarithm of the killing time in minutes makes an arithmetical progression, this time-temperature logarithmic formula as time- 

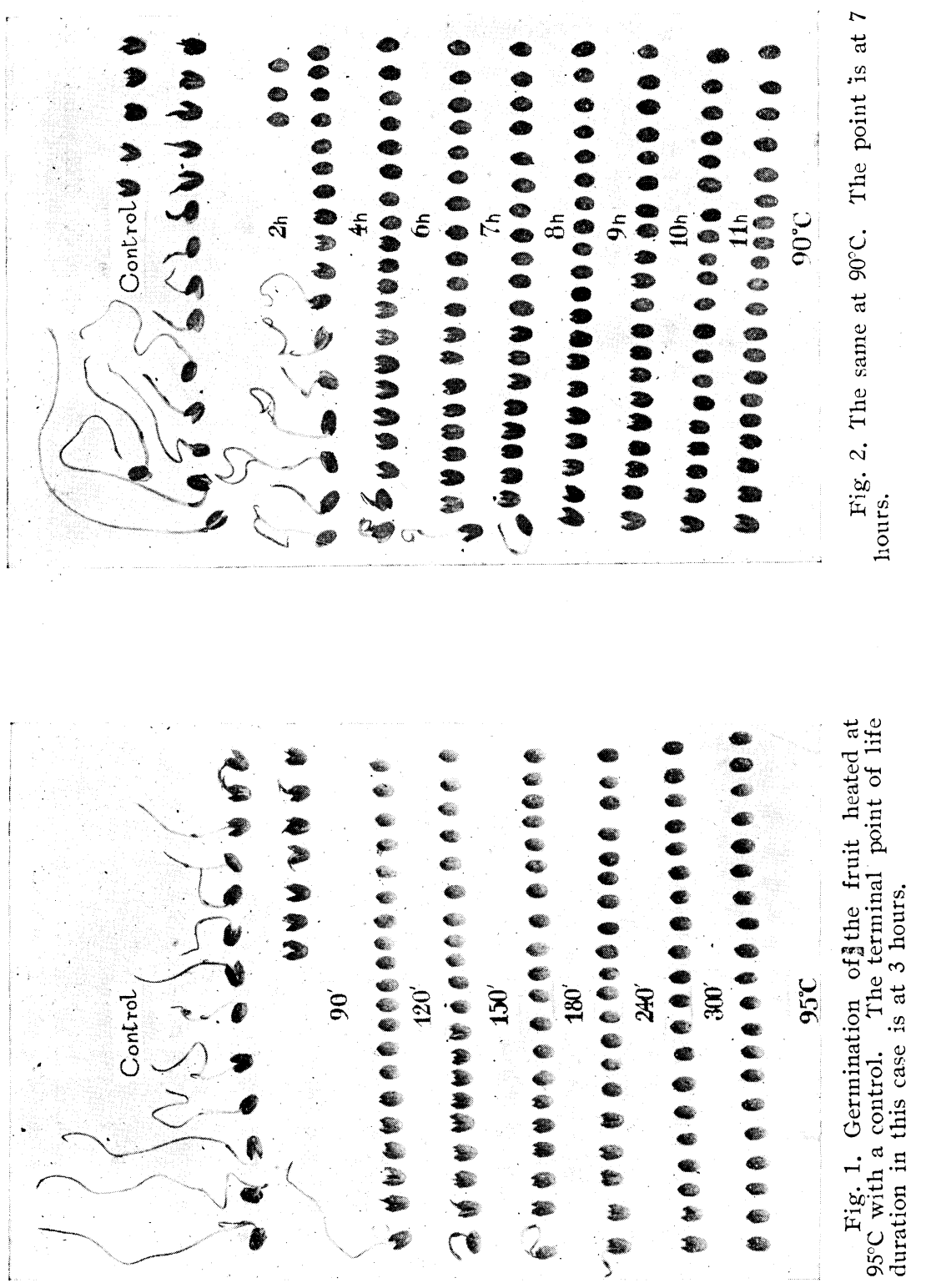


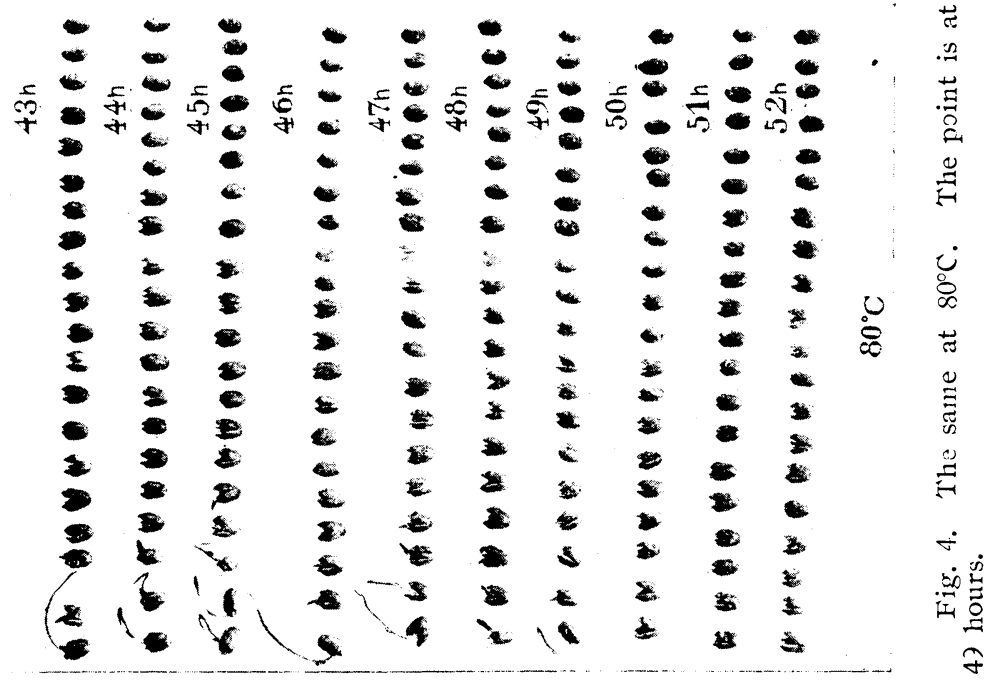

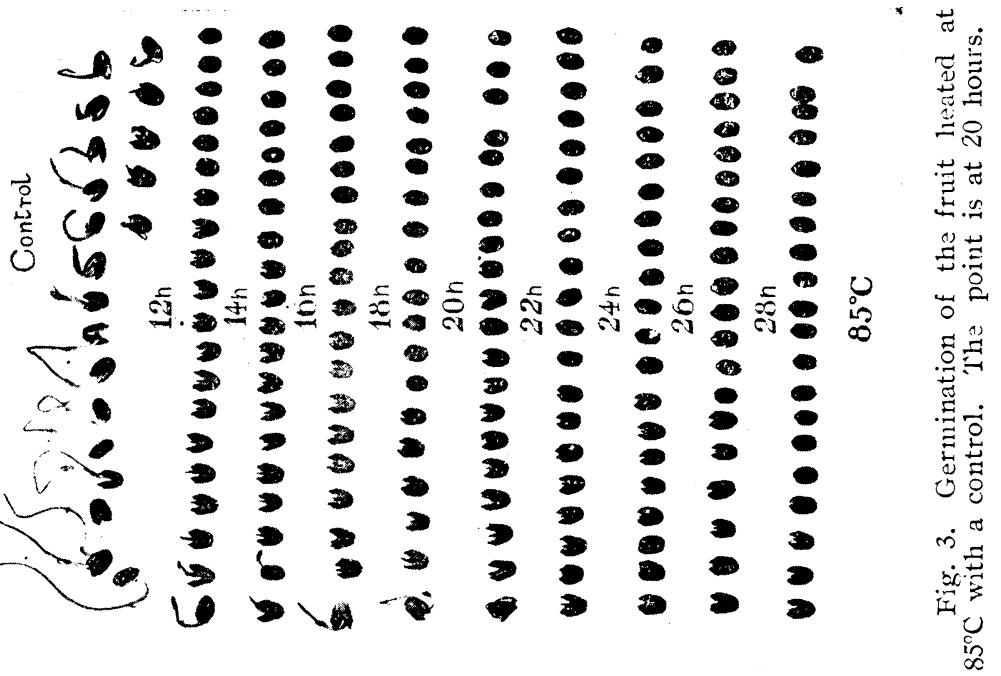


Table I

\begin{tabular}{|c|c|c|c|c|c|c|c|c|c|c|c|}
\hline \multicolumn{2}{|c|}{$\begin{array}{l}\text { Temperature } \\
\text { in } \mathrm{C} \text {. }\end{array}$} & $120^{\circ}$ & $110^{\circ}$ & $105^{\circ}$ & $100^{\circ}$ & $95^{\circ}$ & $90^{\circ}$ & $85^{\circ}$ & $80^{\circ}$ & $75^{\circ}$ & $70^{\circ}$ \\
\hline \multicolumn{2}{|c|}{$\begin{array}{l}\text { Time intervals in } \\
\text { min. taking out } \\
\text { of the bath } \\
\end{array}$} & $10^{\prime}$ & $15^{\prime}$ & $20^{\prime}$ & $30^{\prime}$ & $30^{\prime}$ & $60^{\prime}$ & $120^{\prime}$ & $\begin{array}{r}60^{\prime} \\
120^{\prime}\end{array}$ & $180^{\prime}$ & $240^{\prime}$ \\
\hline $\begin{array}{l}Z \\
0 \\
0\end{array}$ & I & 0 & $15^{\prime}$ & $60^{\prime}$ & $120^{\circ}$ & $* 180^{\prime}$ & $480^{\prime}$ & $1260^{\prime}$ & $2880^{\prime}$ & \multirow{6}{*}{$\begin{array}{l}7620^{\prime} \\
7440^{\prime}\end{array}$} & \multirow{6}{*}{$\begin{array}{l}19800^{\prime} \\
18960^{\prime}\end{array}$} \\
\hline 욤 & II & 0 & $30^{\prime}$ & $30^{\prime}$ & $120^{\prime}$ & $210^{\prime}$ & $510^{\prime}$ & $1320^{\prime}$ & $3120^{\prime}$ & & \\
\hline 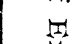 & III & 0 & $15^{\prime}$ & $45^{\prime}$ & $90^{\prime}$ & $180^{\prime}$ & $480^{\prime}$ & $* 1200^{\prime}$ & $3000^{\prime}$ & & \\
\hline$\overbrace{i \infty}^{x}$ & IV & & & & $60^{\prime}$ & $210^{\prime}$ & $* 420^{\prime}$ & $1320^{\prime}$ & $* 2940^{\prime}$ & & \\
\hline$\stackrel{3}{\Xi}$ & $\mathrm{V}$ & & & & $90^{\prime}$ & & $480^{\prime}$ & $1320^{\prime}$ & & & \\
\hline$\underset{\Theta}{\stackrel{\Xi}{\Xi}}$ & VI & & & & & & $540^{\prime}$ & & & & \\
\hline \multicolumn{2}{|c|}{$\begin{array}{l}\text { Average of } \\
\text { terminal } \\
\text { point }(Z)\end{array}$} & 0 & $20^{\prime}$ & $45^{\prime}$ & $96^{\prime}$ & $190^{\prime}$ & $485^{\prime}$ & $1284^{\prime}$ & $29.85^{\prime}$ & $7530^{\prime}$ & $193 S^{\prime}$ \\
\hline \multicolumn{2}{|c|}{$\begin{array}{c}\text { Logarithm of } \\
\text { above }\end{array}$} & 0 & 1.30103 & 1.65301 & 1.98227 & 2.27875 & 52.68574 & 3.10857 & 3.47494 & 3.87679 & 4.28735 \\
\hline \multicolumn{2}{|c|}{$\begin{array}{c}\text { Difference of } \\
\text { above }\end{array}$} & \multicolumn{10}{|c|}{0.3519 .80 .329260 .295930 .406690 .422830 .366370 .401850 .41064} \\
\hline \multicolumn{2}{|c|}{ Calculated time } & & $11^{\prime}$ & $30^{\prime}$ & $66^{\prime}$ & $191^{\prime}$ & $482^{\prime}$ & $1216^{\prime}$ & $3070^{\prime}$ & $7746^{\prime}$ & $19543^{\prime}$ \\
\hline
\end{tabular}

* The ones for which the pictures in Figs. 1-4 were taken.

life duration formula was applied for below $100^{\circ} \mathrm{C}$ and also for all cases. In the former case, constant $a$ is 123.38 and $b$ is 12.44 and in the latter case $a$ is 12.62 and $b$ is 13.37. When calculated, the former constants closely agree with the found number and predicted life duration at lower temperature comes out as follows:

Table II

\begin{tabular}{|c|c|c|c|}
\hline $\begin{array}{l}\text { Temperature } \\
\text { in C. }\end{array}$ & Calculated time & $\begin{array}{c}\text { Temperature } \\
\text { in } \mathrm{C} .\end{array}$ & Calcutated time \\
\hline $100^{\circ}$ & $66^{\prime}$ ( 1.1 hours $)$ & $60^{\circ}$ & 86.4 days $^{\circ}$ \\
\hline $95^{\circ}$ & $191^{\prime}(3.2 " \prime)$ & $50^{\circ}$ & 1.9 years \\
\hline $90^{\circ}$ & $482^{\prime}(8.0 ")$ & $40^{2}$ & $9.6 \mathrm{\prime \prime}$ \\
\hline $85^{\circ}$ & $1216^{\circ}(20.3 \|)$ & $30^{\circ}$ & $61.1 \mathrm{II}$ \\
\hline $80^{\circ}$ & $3070^{\prime}(2.1$ days $)$ & $20^{\circ}$ & 398.7 " \\
\hline $75^{\circ}$ & $7746^{\prime}(5.4 \quad)$ & $10^{\circ}$ & $2474.5 \quad$ \\
\hline \multirow[t]{2}{*}{$70^{\circ}$} & $19543^{\prime}(13.6 ")$ & $5^{\circ}$ & $6243.1 "$ \\
\hline & & $0^{\circ}$ & $15755,4 \quad$ \\
\hline
\end{tabular}

$\left(\mathrm{A}-\mathrm{A}^{\prime}\right)$ line in Fig.5 is a time-temperature curve representing the experimental data shown in Table II, in which the ordinates represent degree Centigrade and the abscissae minutes of time. All the points 


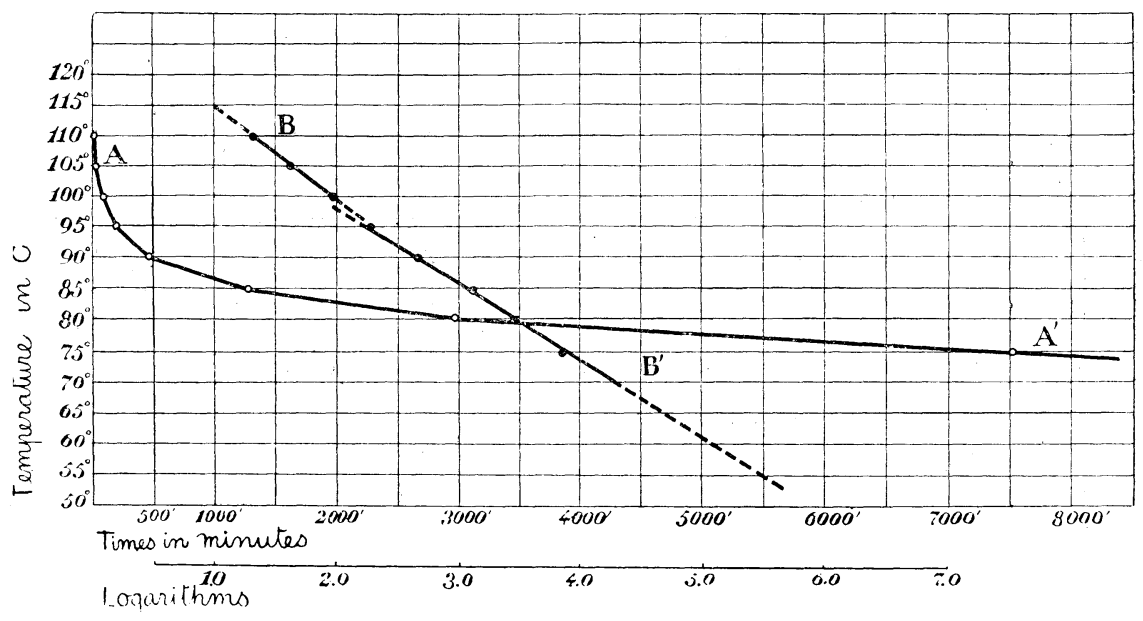

Fig. 5, The relation between temperature and life duration. Temperature in $\mathrm{C}$ on the ordinates and life duration in minutes and their logarithms on the abscissae. I,ine $\left(A-A^{\prime}\right)$ shows the curve of found values and line $\left(B-B^{\prime}\right)$ the logarithmic values.

representing the experimental data fall upon a smooth curve. In $\left(\mathrm{B}-\mathrm{B}^{\prime}\right)$ line of Fig.5, the temperature is plotted against the logarithm of time and this makes a smooth straight line. If we elongate this line downwards, all the points which intersect with temperature line indicate approximately their logarithms of time in minutes at the lower temperatures.

\section{Discussion and Conclusion}

That coagulation of proteins in the living cell is the function of temperature and the concentration of plasm was contended for by ChICK and MARTin and others. Seeds must have some amount of water in them, if they are alive just as water of crystallization in chemicals, and if the coagulation of proteins in the cell means the loss of vitality, it becomes a function of temperature when water content is constant. This coagulation or killing temperature is not fixed as in the case of the boiling or freezing point of chemicals. And as coagulation is a phenomenon of a change of a colloidal state, it is no wonder that the temperature coefficient does not agree with VAN'T HOFF's law ${ }^{(16)(18)}$.

The writer ${ }^{(23)}$ has determined the age of the ancient Indian Lotus fruit in peat near Pulantien as at least 160 or 250 years and considers it to be the fruit with the longest vitality in the plant world. GROVEs ${ }^{(19)}$, in wheat, observed and calculated that from Miss WHITE's and his own data the temperature-life duration curve agrees with an 
actual age of the seed. This agreement is a unique example of this line. Such similar determinations should be made for several seeds. The writer is not aware in what state the Indian Lotus fruit exists in a pond. It is certain, however, that the fruit, after ripening, floats on the surface of water and germinates by swelling either on the surface of water or in the mud at the bottom. In his experiment, a new fruit kept in tap water for a year germinated about $15 \%$ and an old one under the same condition about $8 \%$. This imperviousness is due to the presence of the hard coat and all the vital processes become dormant in the seeds.

According to the data of the Japanese Government Observatory, the soil temperature at Dairen and Yingkou is as follows :

Table III

\begin{tabular}{|c|c|c|c|c|c|c|c|c|c|c|c|c|c|c|c|c|}
\hline Mon & 式 & $\frac{1}{0}$ & $\underset{7}{\stackrel{2}{2}}$ & $\underset{: 2}{2}$ & $\underset{2}{2}$ & $\stackrel{\Xi}{\Xi}$ & $\stackrel{\varpi}{\Xi}$ & 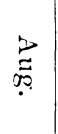 & $\stackrel{\mathscr{W}}{\stackrel{\mathscr{C}}{+}}$ & $\begin{array}{l}0 \\
? \\
+\end{array}$ & \begin{tabular}{l}
$Z z$ \\
0 \\
\hdashline
\end{tabular} & 퓽 & 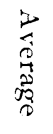 & $\underset{0}{3}$ & 总 & 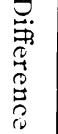 \\
\hline $0.1 \mathrm{~m}$. & -3.2 & -2.1 & 1.9 & 8.9 & 15.8 & 21.1 & 24.5 & 25.2 & 20.2 & 13.7 & 5.9 & 0.0 & 11.0 & 29.2 & -9.3 & 37.8 \\
\hline $0.2 \mathrm{~m}$. & -2.8 & -1.9 & 1.5 & 8.1 & 14.9 & 20.2 & 23.9 & 23.9 & 20.3 & 14.0 & 6.5 & 0.6 & 10.9 & 27.5 & -9.7 & 36.0 \\
\hline 0.3111. & -1.7 & -1.2 & 1.7 & 8.2 & 14.8 & 20.1 & 23.7 & 21.9 & 24.9 & 15.0 & 7.6 & 1.8 & 11.3 & 27.6 & -8.5 & 33.1 \\
\hline $0.5 \mathrm{ml}$ & 0.1 & -0.2 & 1.9 & S.1 & 14.1 & 19.2 & 22.7 & $2+1.2$ & 24.2 & 16.2 & 9.3 & 3.6 & 11.7 & 26.1 & -8.5 & 27.8 \\
\hline
\end{tabular}

Temperature in soil at Dairen (average of 22 years' observations)

Table IV

\begin{tabular}{|c|c|c|c|c|c|c|c|c|c|c|c|c|c|c|c|c|}
\hline $\mathrm{MO}$ & 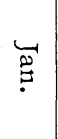 & $\begin{array}{l}71 \\
0 \\
0\end{array}$ & $\begin{array}{l}\text { 占 } \\
\stackrel{2}{2} \\
\stackrel{7}{*}\end{array}$ & 蛋 & 蛋 & $\stackrel{\stackrel{c}{a}}{\Xi}$ & $\stackrel{\Xi}{\Xi}$ & $\underset{\infty Q ⿻}{\stackrel{D}{a}}$ & 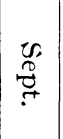 & $\begin{array}{l}0 \\
\stackrel{+}{+}\end{array}$ & \begin{tabular}{l}
$Z$ \\
0 \\
\hdashline \\
\end{tabular} & $\begin{array}{l}\underset{D}{0} \\
?\end{array}$ & 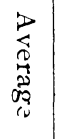 & 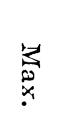 & 苛 & $\begin{array}{l}\underset{G}{\exists} \\
\underset{0}{0} \\
0 \\
0 \\
0 \\
0 \\
0\end{array}$ \\
\hline $0.1 \mathrm{~m}$. & -9.2 & -4.9 & $\cdot 0.5$ & 7.8 & 15.8 & 21.9 & 25.8 & 25.5 & 18.8 & 11.0 & 1.9 & -5.3 & 9.1 & 33.8 & -14.8 & 48 \\
\hline $0.2 \mathrm{~m}$. & -6.6 & -4.5 & -0.7 & 7.0 & 15.1 & 20.4 & 24.9 & 25.4 & 19.4 & 12.5 & 3.9 & -3.6 & 9.4 & 28.9 & -12.8 & 41. \\
\hline $0.3 \mathrm{~m}$. & 5.5 & -3.7 & -0.5 & 6. & 14.8 & 20.6 & 24.7 & 2.5 .3 & 19.9 & 13.2 & 4.5 & -2.0 & 9.8 & 29.7 & -10.6 & 40. \\
\hline $0.5 \mathrm{~m}$ & -2 & 2.5 & -0.8 & 5.2 & 136 & 19.5 & 22.7 & 24.0 & 20.5 & 14.9 & 7.1 & 0.9 & 10.1 & 25.1 & -6.5 & 32 \\
\hline
\end{tabular}

Temperature in soil at Yinglou (average of 22 years' observations)

Pulantien is located 77 miles north from Dairen and 184 miles south from Yingkou. The soil temperature at 0.5 metres in depth at these two stations ranges from $26.1^{\circ}$ to $-8.6^{\circ} \mathrm{C}$ a year.

I APESCHKin found that in an active cell a redispersal process of cell proteins is going on coincidentally with coagulation. However Grovis holds that the redispersal process is not going on in 
relatively dry seeds and that in seeds the calculated values are usually much greater than records of longevity in room temperatures. And also a slight error in the value of the constant $a$ and $b$ of the logarithmic formula will grive a relatively large absolute error for life duration at low temperature. At higher temperatures the absolute error becomes less. Though we can not estimate the longevity of the Indian Louts fruit botanically, historically, or topographically, the writer, from these points of view, might predict that those kept in the soil at temperatures ranging from $30^{\circ}$ to $-10^{\circ} \mathrm{C}$ and in about $10^{\circ} \mathrm{C}$ in average might live some thousand years.

It was further observed that when the fruit was kept to cool in liquid air a week, it still germinated. It shows that the low temperature produces very little effect on dry. seeds, as BECQUEREL (3) proves.

\section{SuMMARY}

1. The longevity of the fruit of ancient Indian Lotus in peat is due to the presence of the hard coat as well as the nature of protoplasm in the embryo.

2. Coagulation of proteins in the living cell is due to the temperature and moisture concentration. As a consequence, if the moisture is constant, the coagulation depends upon the temperature.

3. At $120^{\circ} \mathrm{C}$ the viability was lost in 10 minutes, while in liquid air the fruit was kept a week without any change in "germinable" power.

4. In the Lotus fruit, temperature-life duration curve showed a logarithmic nature. So LEPESCHKIN's time-temperature formula was applied with success.

5. From experimentally found value and from the value calculated by the logarithmic formula, we might predict the longevity of the fruit in the Pulantien soil to be some thousand years.

The writer wishes to express his grateful acknowledgement to Professor K. FUJII who suggested him to study on this subject and encouraged and helped to complete it during the course of investigation. 


\section{LITERATURE}

1. BABCock, S. M. Metabolic water: Its production and role in vital phenomena. Wisconsin Agric. Ixp. Sta. Bull., 22 : 1912.

2. Prass, W. J. Tha vitality of seeds buried in the soil. Bot. Gaz., 40: 140-143. 1905.

3. Becquerer, P. Recherche sur la vie latente des graines. Ann. Sci. Nat. Bot., 40: 193-320. 1907.

4. BERGTHEIn, C. and I)AY. A. I. On the course of "Hardness" in the seeds of Indigofera arrecta. An11. of Bot., 21: 57-60. 1907.

5. Buglia, G. Über die Hitzegerinnung von flüssigen und festen organischen Kolloiden. Zeits. Chem. Ind. Kolloide, 5 : 291-293. 1909.

6. ChICK, H. and MAR'TIN, A. J. On heat coagulation of proteins. Journ. Physiolog., 40 : 404-430. 1910.

7. Crockrir, W. Rôle of seed coats in delayed germination. Bot. Gaz., 42 : 265291. 1906.

8. Crocker, W. Germination of seeds of water plants. Bot. Gaz., 44 : 375-380. 1907.

9. Crocker, W. Longevity of seeds. Bot. Gaz., 47: 69-73. 1909.

10. Crocker, W. and DAvis, W. F. Jelayed germination in seed of Alisma plantago. Bot. Gaz., 58 : 285-321. 1914.

11. Crockir, W. and Groves, I. F. A method of prophesying the life duration of seeds. Proc. Nat. Acad. Sci., 1 : 152-155. 1915.

12. Crocker, W. Mechanics of dormancy of seeds. Am. Journ. Bot., 3: 99-120. 1916.

13. Duvis, J. W. T. Vitality of buried seeds. U. S. I). A. Bur. B1. Ind., 83: 1-20. 1905.

14. EWART, A.J. On the longevity of seeds. Proc. Roy. Soc. Victoria, 21 : 1-120. 1908.

15. Gross, W.L. The vitality of buried seeds. Jour. Agr. Res., 29 : 349-362. 1924.

16. Groves, J.F. Temperature and life duration of seeds. Bot. Gaz., 63: 169-189. 1917.

17. Guppy, H.B. Studies in seeds and fruits. 1912.

18. Kanitz, A., Temperatur und Lebensvorgänge. 1915.

19. LFPESCHKIN, W. W. Zur Kenntnis der Einwirkung supramaximaler Temperaturen auf die Pflanze. Ber. Deut. Bot. Gesells., 30 : 703-714. 1913.

20. Morisch, H. Pflanzenphysiologie als Theorie der Gärtenerei. VI. Auf1. 288-301. 1921.

21. OHG.t, I. On the longevity of fruit of Nelumbo nucifera. Bot., Mag. Tokyo, 37 : 87-95. 1923.

22. OHGs. I. On the structure of some ancient, but still viable fruits of Indian Lotus, with special reference to their prolonged longevity. Jap. Jour., Bot. 3 : 1-20. 1926.

23. OHGA, I. On the age of the ancient fruit of the Indian Lotus which is kept in the prat bed in South Manchuria. Bot. Mag., Tokyo, 41 : 1-6. 1927.

24. OHGA, I. The gerinination of century-old and recently harvested Indian Lotus fruits, with special reference to the effect of oxygen supply. Am. Journ. Bot., 13 : 754-759. 1926.

25. OHGl, I. A comparison of the life activity of century-old and recently harveste:1 Indian Lotus fruits. Am. Journ. Bot., 13: 760-765. 1926.

26. Peter, A. Culturversuche mit "ruhenden Samen". Nacht. Koekigl. Ges. Wiss. Georg-Univ. zu Göttingen, 17: 673-691. 1893; Ibid. 18: 373-393. 1894.

27. WHITE, J. The occurrence of an impermeable cuticle on the exterior of certain 
seeds. Proc. Roy. Soc. Victoria, 21 : 203-210. 1907.

8. White, J. Ferment and latent life of resting seed. Pro. Roy. Soc. B, 81: 417442. 1909.

29. WirTMACK, L. Landwirtschaftliche Samenkunde. 91-102. 1922.

\title{
On the Structure of Diplasium esculentum, (RETZ.) SW.
}

\begin{abstract}
Contributions to Cytology and Genetics from the Departments of PlantMorphology and of Genetics, Botanical Institute, Faculty of Science, Tokyo Imperial University, No. 62
\end{abstract}

By:

\section{Y. Ogura}

\section{With 4 Text-Figures}

Some species of the Polypodiaceae are characterized by their possessing stems showing di- or polycyclic stelar system. In these cases, the internal meristeles or medullary bundles are formed from the outer stelar ring by means of internal thickening and subsequent separation, the separated meristeles or bundles, after running some distances upwards, being fused to the outer ring at the leaf-gap.

A type of dicyclic stele, which is somewhat different from the above cases and rather resembling that of the Cyatheaceae, was found in the stem of Diplazium esculentum, a Polypodiacean treefern from tropical regions of Asia and the Polynesias. The material was collected at Koochoo (Kusshaku), near Taihoku, Formosa, in August 1925.

\section{A. EXTERNAL FFATURES}

This plant is a small tree-fern having an erect stem, the height of which attains $20-30 \mathrm{~cm}$. The largest specimen which was observed by the writer has the stem as high as $40 \mathrm{~cm}$. (Fig. 1). Living leaves, with short petioles and bipinnate laminae, are limited to the top of the stem, and older ones are shed leaving their basal parts, which closely cover the stem. Roots, subterranean or near the 